Please do not remove this page

RMIT

UNIVERSITY

\title{
Bundling and stacking in bio-sequestration schemes: Opportunities and risks identified by Australian stakeholders
}

Torabi, Nooshin; Bekessy, Sarah

https://researchrepository.rmit.edu.au/esploro/outputs/9921862553101341/filesAndLinks?institution=61RMIT_INST\&index=null

Torabi, N., \& Bekessy, S. (2015). Bundling and stacking in bio-sequestration schemes: Opportunities and risks identified by Australian stakeholders. Ecosystem Services, 15, 84-92.

https://doi.org/10.1016/j.ecoser.2015.08.001

Document Version: Accepted Manuscript

Published Version: https://doi.org/10.1016/j.ecoser.2015.08.001

Repository homepage: https://researchrepository.rmit.edu.au

(C) 2015 Elsevier B.V. All rights reserved.

Downloaded On 2023/04/26 19:50:56 +1000 
Thank you for downloading this document from the RMIT Research Repository.

The RMIT Research Repository is an open access database showcasing the research outputs of RMIT University researchers.

RMIT Research Repository: http://researchbank.rmit.edu.au/

\section{Citation:}

Torabi, N and Bekessy, S 2015, 'Bundling and stacking in bio-sequestration schemes: Opportunities and risks identified by Australian stakeholders', Ecosystem Services, vol. 15, pp. 84-92.

See this record in the RMIT Research Repository at:

https://researchbank.rmit.edu.au/view/rmit:33707

Version: Accepted Manuscript

\section{Copyright Statement:}

(C) 2015. This manuscript version is made available under the CC-BY-NC-ND 4.0 license http://creativecommons.org/licenses/by-nc-nd/4.0/

\section{Link to Published Version:}

http://dx.doi.org/10.1016/j.ecoser.2015.08.001 


\section{Bundling and stacking in bio-sequestration schemes: opportunities and risks identified by Australian stakeholders}

Nooshin Torabi ${ }^{a}$, Sarah Bekessy ${ }^{a}$

*Corresponding author

${ }^{a}$ Interdisciplinary Conservation Science Group, School of Global, Urban and Social Studies, RMIT University, Melbourne, VIC 3000, Australia

E: nooshin.torabi@rmit.edu.au, sarah.bekessy@rmit.edu.au

Ph: $\quad+61399250909$ 


\section{Abstract}

The stacking and bundling of ecosystem services credits has emerged as mechanisms to promote the conservation of biodiversity in carbon sequestration schemes. Globally, apart from a few certification standards in the voluntary market, little genuine action has eventuated, but actors in these markets are continuing to examine the idea of combining carbon and biodiversity credits. This paper provides the first empirical analysis of the opportunities and barriers of bundling and stacking carbon and biodiversity credits as articulated by policymakers and academics, in Australia. Corporate social responsibility (CSR) acts as a driving force for business interest in the co-benefits of carbon plantings; however, uncertainty in the market and policy settings act as barriers for both buyers and sellers. Interviewees highlighted substantial benefits of both bundling and stacking, including easing transaction costs for landholders, reduced monitoring costs for regulators. Nevertheless, there is a risk that stacking can affect the perceived additionality of carbon plantings, which has the potential to erode the integrity of carbon markets. Obstacles to the establishment of stacked/bundled markets include the lack of standards to show that co-benefits are real, dealing with the additionality rule, and designing scenarios to achieve genuine outcomes for both biodiversity conservation and carbon abatement.

Keywords: Biodiversity conservation, bio-sequestration, bundling credits, stacking credits, ecosystem services, trade-offs

\section{Highlights:}

- We investigated various carbon and biodiversity market options in Australia

- Interviewing stakeholders revealed bundling is currently the most promising option

- Accurate measures and standards demonstrating achievement of co-benefits are needed

- Uncertainties in the carbon market \& political setting restrict bundling/stacking

- It is essential to establish clear objectives for bundled/stacked markets 


\section{Introduction}

Increasing public concern about climate change has generated a market for greater investment in bio-sequestration projects (the capture and storage of atmospheric carbon through tree planting; (Bekessy and Wintle 2008; Venter, et al. 2009; Crossman et al. 2011). Payment for ecosystem services enables landholders to reap the benefits of two or more services on the one piece of land while also providing benefits to the public (Deal et al., 2012). Biodiverse plantings for carbon sequestration, where a diversity of tree species are planted, is an example of a potentially synergistic service whereby greenhouse gas emissions are sequestered and biodiversity is conserved. To encourage participation in biodiverse plantings for carbon sequestration, private landholders and investors should be able to take advantage of both ecosystem service markets (the carbon market and biodiversity market) on the one piece of land (Bekessy and Wintle 2008). These two global ecosystem service markets have the potential to help private landowners generate income while benefiting both climate change abatement and biodiversity conservation (Venter et al. 2009).

High transaction costs in establishing carbon plantings (Cacho et al., 2013) and carbon market uncertainty among landholders (Kragt et al. 2014; Maraseni and Dargusch 2008) are likely to reduce the uptake of carbon planting schemes. At the start of any new scheme (e.g., the Carbon Farming Initiative in Australia (Australian Government, 2011)), obtaining information is a costly first step, and is followed by establishment costs (labour, seedlings), project approval, monitoring and ongoing related costs (Cacho et al., 2013; Crossman et al., 2011; Galik et al., 2012). Under higher carbon price scenarios, the opportunity cost for landholders to plant trees instead of grazing or cropping will impact their decisions (Cacho et al., 2013). However, if the price of carbon is insufficient to cover all of the transaction costs, landholders will need additional incentives to cover their expenses and encourage them to participate (Crossman et al., 2011).

To better incentivise landholders for the biodiversity outcomes of carbon plantings, standards and a process for monitoring biodiversity outcomes are needed (Carswell and Burrows 2006). This was confirmed in a Victorian Department of Sustainability and Environment investigation of the biodiversity outcomes of bio-sequestration schemes by surveying a selection of Australian offset providers (Kapambwe and Keenan 2009). The study revealed that offset providers 
involved in bio-sequestration are concerned about a lack of incentives and a clear set of standards for biodiversity outcomes of bio-sequestration projects (Kapambwe and Keenan 2009). Once developed, such standards would require consideration of the restoration outcomes of biodiverse plantations (compared to a "reference ecosystem benchmark") to achieve the delivery of large-scale conservation co-benefits (Standish and Hulvey 2014 p.27).

Bundling and stacking credits from different ecosystem services are concepts gaining global attention (EPRI, 2011; Robertson et al., 2014; Van der Biest et al., 2014). Both bundling and stacking have the potential to be utilised as mechanisms to better incentivise landholders and to provide improved options for buyers in ecosystem services markets (Deal et al., 2012). Stacking ecosystem service credits refers to multiple credits generated from one piece of land being sold separately in the relevant markets (Robertson et al., 2014). For example, biodiversity gains, controlling water regimes and carbon sequestration benefits from biodiverse plantations can be stacked (Deal et al., 2012). Carbon and biodiversity credits could be sold in their respective markets separately (unstacked) to meet specific regulatory requirements. Stacking could provide incentives for landholders to deliver higher quality projects; for example, in addition to planting riparian vegetation, wetlands could be restored to provide multiple ecosystem services credits (water quality, wetland restoration, biodiversity conservation) (Cooley and Olander, 2011). However, care must be taken to ensure that these services are discrete and additional to avoid the common concern of regulatory bodies for the potential for 'double-dipping' (Woodward, 2011).

Bundling credits refers to selling multiple ecosystem services from one piece of land (i.e. biodiverse carbon credits) as a combined 'ecosystem credit'; it is up to the structure of the market to allow such transactions (Deal et al., 2012). Bundled credits cannot be sold separately in their respective markets. An example of bundled credits is 'premium carbon' whereby buyers pay a higher price for carbon that is sequestered with the co-benefit of biodiversity conservation.

Schemes for encouraging bundling and stacking credits for ecosystem services need to be designed carefully to achieve the desired ecological outcomes (Bryan 2013; Venter et al. 2009). This is partly because of the complexity of trade-offs between different ecosystem services (Baral et al., 2014; Bryan, 2013). In the case of carbon and biodiversity, it is possible that greater 
amounts of carbon could be sequestrated with monoculture plantations, but biodiversity conservation objectives would not be met (Kanowski and Catterall, 2010). However, biodiverse plantings for carbon sequestration could increase the biodiversity co-benefits and indeed have the potential to sequester equivalent carbon when uncertainties surrounding fire, drought and pests are considered (Bekessy and Wintle, 2008; Lin et al., 2013) . Kinzig et al. (2011 p.604) also argued that in the case of producing multiple ecosystem services from one piece of land, "paying for only one service can be as damaging as paying for none". This is because paying for multiple ecosystem services could increase the likelihood of environmentally beneficial outcomes (e.g. wetland restoration instead of riparian revegetation) (Cooley and Olander, 2011). The dynamic between different ecosystem services (e.g., biodiversity and biomass (Kirchner et al., 2015) requires careful consideration for designing the incentives to manage those services without jeopardising one while achieving the others (Fargione et al., 2008; Horan et al., 2008; Kolinjivadi et al., 2015). However, Kirchner et al. (2015) argued that despite the trade-offs, opportunities exist to promote synergies between ecosystem services.

Electric Power Research Institute (EPRI) conducted a survey in the USA to capture opinions about bundling and stacking credits. Credit buyers and sellers (wetlands, water, species and carbon credits), academics and policymakers in the field (wetland and species credits) active in the markets for ecosystem services participated in the survey (EPRI, 2011). More than 40 per cent of survey respondents believed that stacking will deliver positive ecological outcomes and 42 per cent that the positive ecological outcomes depend on the details of the stacking scenario (EPRI, 2011). However, in North Carolina, stacking credits for water quality improvement and wetland biodiversity have been criticised by academics and policymakers for 'double-dipping' and not achieving the net gain in restoration (Kenny 2010 in Robertson 2012). In this study we qualitatively explore the perspectives of experts on stacking/ bundling ecosystem services credits and discuss practical issues (e.g. market and policy) in design and implementation of such policies.

Corporate social responsibility (CSR) (Di Giuli and Kostovetsky 2014) and mandatory requirements (Freedman et al., 2009; Tvinnereim, 2014) act as drivers for businesses to invest in bundled credits for ecosystem services (Bekessy and Wintle 2008). Bundled credits have the potential to be seen as a 'public good'. Bundling and stacking should also appeal to private landholders seeking additional revenue sources to cover the establishment and transaction 
costs of biodiverse plantings for carbon sequestration. However, market and political uncertainty could reduce the attractiveness of such investments (Kragt et al., 2014). Political certainty attracts buyers and sellers, creates a better functioning market, and drives research and practical innovation towards bundling and stacking ecosystem services (Watson et al., 2014); the ultimate consequences could be novelty in the market for ecosystem services and diversity of credits generated from those services provided by natural resources.

This paper explores the opportunities and risks of bundling and stacking carbon and biodiversity credits from the perspectives of policy experts and academics in Australia. We provide the first empirical analysis in this context, interviewing stakeholders who are involved in guiding or implementing these schemes on the ground. Our research builds on the survey results of EPRI (2011) and other theoretical analyses (Robertson et al., 2014) to gain a deeper understanding of the opportunities and risks of bundled and stacked ecosystem service markets. We conclude with some recommendations for the development of stacked/bundled markets. Australia presents a valuable case study because it has an established history of voluntary biodiverse plantings for carbon sequestration and has recently introduced a range of regulated markets under the Emission Reduction Fund (Commonwealth of Australia, 2014). Lessons learnt in the Australian context will have international relevance as similar market and policy issues are of global concern.

\section{Materials and Methods}

\subsection{Current carbon and biodiversity policy settings}

There are two key policy instruments relevant to the management of carbon and biodiversity on private land in Australia: The Carbon Farming Initiative (CFI) and biodiversity offsetting.

\subsubsection{Carbon Farming Initiative (CFI)}

The CFI was legislated in the Australian Federal Parliament in August 2011 with the aim of reducing emissions and establishing tradeable carbon credits (Australian Carbon Credit Units (ACCUs) through enhanced land management practices (Australian Government, 2011). Since the repeal of the Carbon Tax in July 2014, the scheme has been supported through the Emission 
Reduction Fund (ERF) as part of the Direct Action policy to tackle climate change and achieve Australia's carbon abatement target (Commonwealth of Australia, 2013). Since the start of the scheme, 4,226,090 ACCUs have been issued (Australian Governmet, 2013). Reforestation is one of the approved methodologies under the CFI (Commonwealth of Australia, 2013). To be eligible, projects must deliver extra reductions to business as usual level in greenhouse gas emissions. This is known as 'additionality' and is a requirement of all offset schemes (Bradshaw et al., 2013; Commonwealth of Australia, 2013). Furthermore, as part of the legal requirements of the Kyoto Protocol, 'permanence' refers to the condition of carbon offsets that requires trees to stay on landholders' properties for 100 years (Commonwealth of Australia, 2013).

\subsubsection{Biodiversity offsets}

Biodiversity loss has become a pressing global issue, not only for its own sake but for the related negative effect on the economy and human well-being (SCBD, 2010). Achim Steiner, executive director of the United Nations Environment Programme (2010) outlined that:

Annual losses as a result of deforestation and forest degradation alone may equate to losses of US\$2 trillion to over US\$4.5 trillion alone. These could be secured by an annual investment of just US\$45 billion: a 100 to 1 return (Secretariat of the Convention on Biological Diversity 2010 p. 6).

To tackle biodiversity loss, different mitigation methods have been undertaken around the globe, from biodiversity banking to one-off offsets (Madsen et al., 2011). Biodiversity offsetting is a mitigation method designed to conserve native vegetation on private land (Gordon et al., 2011b). In the Australian states of New South Wales and Victoria respectively, private landowners can generate 'biodiversity credits' and 'native vegetation credits' by enhancing biodiversity outcomes in their properties through 'Biobanking' and 'BushBroker' agreements (Department of Sustainability and Environment, 2011; Office of Environment and Heritage, 2011). Developers are responsible for the ongoing monitoring of the offset sites to maintain the no net loss or net gain achievements in the biodiversity condition of the developed sites (Burgin, 2008). Importantly, management actions at the offset site must be additional to the 'business as usual' scenario to improve the condition of it and achieve net gain (Gordon et al., 2011a), otherwise the offset would not meet additionality requirements. 
The opportunity to stack biodiversity credits with other ecosystem services (like carbon sequestration) was recently introduced in the draft policy paper Draft NSW Biodiversity Offsets Policy for Major Projects (State of NSW and Office of Environment and Heritage, 2014). The proposal states that:

Land management requirements for the purpose of creating carbon credits are not considered to be legal requirements for biodiversity management under this policy. This means that the same site can potentially generate both biodiversity credits and carbon credits through the same management actions. (State of NSW and Office of Environment and Heritage 2014 p.9)

This proposal is the first formal Australian recognition of the stacking credits concept; however, the final document has yet to be released.

\subsection{Interviews}

We interviewed 14 policymakers and academics active in the field of carbon and biodiversity in Australia. The interviews were undertaken either face-to-face or over the phone during the period October 2012 to September 2013. Interviewees were chosen through snowball sampling (chain referral) whereby experts within relevant professional networks were contacted to participate in the interviews and then asked to recommend other suitable stakeholders to interview, hence growing the sample size of the study (Bryman, 2004). The recommended stakeholders were invited for an interview based on their publication record in the related field or the number of years they were involved in design or implementation of biodiverse plantings for carbon sequestration.

Interviewees included actors in various public and private agencies ranging from State and Federal government organisations to not-for-profit organisations as shown in Figure 1. Our rationale for conducting in-depth semi-structured interviews was to obtain comprehensive individual data about their experiences, perceptions and opinions. This provided experiential data from different points of view. We chose interviews over fixed response surveys in an effort to capture rich, nuanced details that are difficult to elicit in more structured methods. The sample size is justified by a 'sampling to saturation' philosophy, whereby interviews continued until no new themes were emerging. We were careful to select different actors in the various 
public and private agencies to capture as much diversity as possible and not to reach saturation prematurely (Glaser and Strauss, 1967). Unlike sampling strategies for quantitative research, the recruitment methods (snowballing) and sample size (14 participants) here do not guarantee generalizability to the population of practioners. This trade off-reliability versus validity-is well known dilemma in the decision to use qualitative, rather than quantitative, methods. Here we have favoured ensuring the latter rather the former.

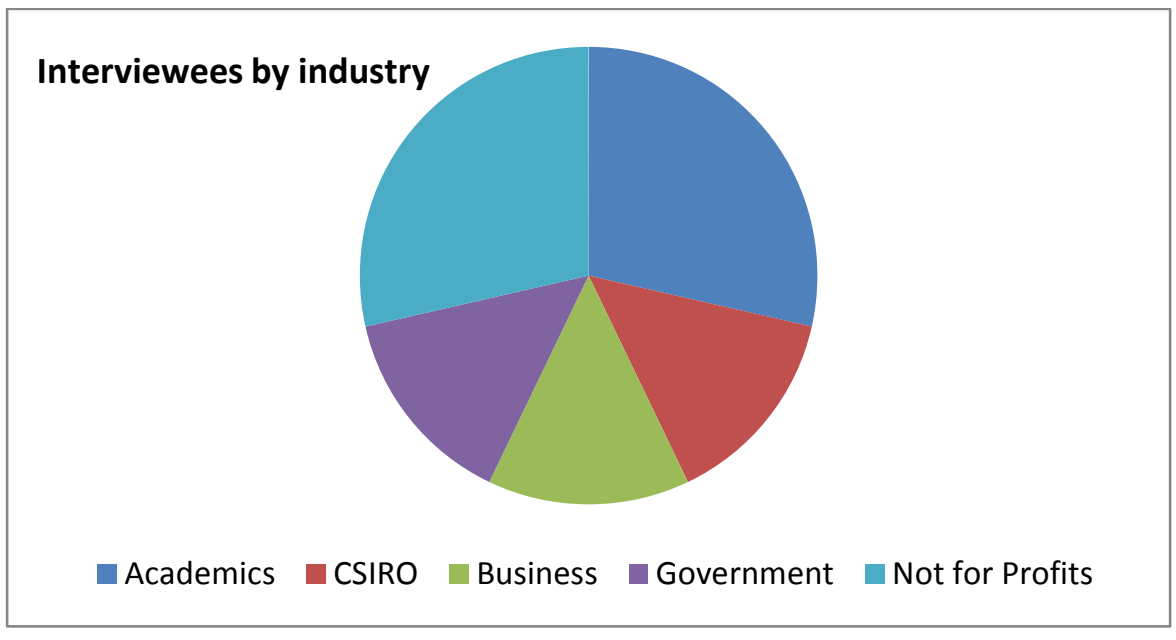

Figure 1: Research interviewees by industry. CSIRO refers to the Commonwealth Scientific and Industrial Research Organisation.

The interviews were semi-structured (Bryman, 2004); their aim was to discover stakeholders' opinions about methods of increasing private landholders' participation in biodiverse plantings for carbon sequestration, specifically exploring the opportunity of stacking or bundling biodiversity and carbon credits. An interview guide was designed to assess interviewees interest in participation (Drever, 1995). Questions targeted stakeholders' opinions about methods of increasing landholders' participation in biodiverse plantings for carbon sequestration (monetary and non-monetary incentives), the feasibility of such incentives given the existing policy setting, and opportunities for policy alteration in favour of both greenhouse gas emissions reduction and biodiversity conservation.

Interviews were digitally recorded, transcribed verbatim and coded in the NVivo 10 software (QSR International, 2012) for content and thematic analysis (Boyatzis, 1998). We were particularly looking for themes about the opportunities and challenges involved in bundling and stacking credits from both market and policy perspectives. We started coding the interviews after the first was conducted. Interviews were continued until we reached the data saturation 
point (Glaser and Strauss 1967) at which no new themes were emerging. To maintain confidentiality we referred to our interviewees as $\mathrm{P}$ (policy actors) and S (scientists) in the results section.

\section{Results}

\subsection{Corporate social responsibility as a driving force}

CSR motivates businesses to voluntarily undertake activities for the social and environmental benefits of the broader community (Clapp and Rowlands, 2015). As one of the interviewees noted, reducing carbon emissions could help businesses maintain their 'green image' in the community.

... there's always the branding opportunities. If a large high-emitting organisation purchases carbon credits from a particular organisation it can improve its image, its corporate social responsibility from where it purchases its credit. (p8)

This interviewee believed that businesses would be willing to pay for the extra costs involved in bundling/stacking ecosystem services credits to improve their national and international image. The cost involved in designing a flexible scheme that offers multiple incentives could increase the price for those credits.

Another participant mentioned the links between CSR and voluntary offsets and existing standards to measure co-benefits. Recognition of biodiversity and social benefits of biodiverse plantings for carbon sequestration as a part of corporate sustainability objectives for businesses could encourage them to get involved in the voluntary offset markets.

Perhaps if there was some incentive for companies to offset locally it might be more of a benefit, and on top of their existing carbon payments maybe they need to top it up with money for social licence to operate or something. But you'd end up reverting back to how it used to be as with voluntary offsets..., yeah, sort of CSR and companies wanting to show to the community what they're doing, which is where all those biodiversity standards came from. (S5) 
This quote also reflects the lack of adequate incentives for businesses to act locally and buy offset credits from national markets instead of sourcing international credits (Michaelowa, 2014).

\subsection{Barriers and challenges for bundling or stacking credits}

Barriers in carbon and biodiversity markets make it less favourable for both landholders and businesses to participate. In addition, uncertainties in the political setting are considered an important barrier (Kapambwe and Keenan, 2009; Maraseni and Dargusch, 2008). Several interviewees reflected that for landholders to undertake carbon plantings on a sufficient scale, certainty in the carbon market and relevant policies were essential. One said:

Obviously you can have models where an intermediary, a specialist company takes that risk [fire] for them, but the farmer still has a risk there. If the carbon market disappears, that company will probably disappear too and so there's nobody left to write the cheques. So you know, I think it's potentially a slightly dangerous space for landholders to be in. If I were a landholder, before I did any serious commercial carbon plantings, I'd be waiting ... right now l'd be waiting to see what happens to the price, what happens to the scheme rules. I wouldn't be getting into any long-term investments right now. (S2)

Another participant reflected slightly differently on the carbon market and Australian policies. “Carbon can come and go - it's a political football, there's an international market that makes it uncertain". As the previous participant mentioned, introduction of any new standard or initiative to better incentivise landholders requires more stability in the market and related policies. This could possibly reduce the demand from buyers to invest in the bundled carbon and biodiversity markets (Meijaard et al., 2014).

Interviewees also mentioned uncertainties in the global political atmosphere regarding tackling climate change and taking meaningful actions in the carbon market.

Let's face it, I haven't seen either Obama or Romney mention climate change in regard to this biggest ever storm going through the US, right! So when you have the biggest country in the world and the opposition leader in Australia essentially you know not even wanting to go do anything serious, then there is clearly a political risk. (S1) 
When the carbon or biodiversity markets are not adequately certain to attract buyers or seller this could impact the success and innovation of schemes that offer additional incentives for other ecosystem services.

\subsection{Moving towards a successful bundling/stacking scenario}

Apart from understanding drivers and barriers in developing stacked or bundled credits for carbon and biodiversity markets, improvement of conditions in favour of bundling or stacking needs consideration from both science and policy perspectives. Prioritising conservation objectives and improving carbon accounting models to accurately reflect the amount of carbon captured by biodiverse plantations are essential parts of moving towards more successful bundled/stacked markets.

\subsubsection{Conservation prioritisation}

Spatial planning at a regional scale could assist the incentivising process. This is because degraded landscapes need immediate action and landholders in those areas could be strategically incentivised to achieve conservation goals in addition to those related to carbon abatement. As one interviewee reflected, one plan may not fit all of the purposes related to carbon sequestration and biodiversity conservation.

In order to make carbon work for biodiversity, we need to identify where our linkages are, where our critical parts of the landscape are and then allow farmers in those areas to forward sell their credits that they're going to have from these future bio-links. ...And I think that would be a really good solution. (P2)

This perspective implies the need for a landscape-scale planning focus to the introduction of bundling or stacking credits, which would require collaboration among different public and private stakeholders.

\subsubsection{Improving carbon modelling techniques}

Currently, the models (e.g. the Full carbon accounting model (FullCAM)) that are applied to calculate the carbon sequestered in biodiverse plantings for carbon sequestration are those developed for monocultures (Paul et al. 2013; Waterworth and Richards 2008). This means that the models are unlikely to accurately reflect the amount of carbon captured by biodiverse plantings for carbon sequestration. Developing models that can accurately calculate the carbon 
sequestered in biodiverse plantings (Paul et al., 2013) will increase the accuracy of carbon monitoring (Waterworth and Richards 2008) and provide more concrete evidence/assurance for buyers in the market. Paul et al. (2013) conducted a project designed to improve FullCAM yield curves for biodiverse plantings, but suggest that their model reflects the carbon capture for young stand mixed-species only. Further research is needed to develop accurate carbon sequestration models for biodiverse plantings for carbon sequestration as the dynamic of mixed-species carbon sequestration will change with age.

Some of the interviewees stated that the first step would be to develop an exclusive carbon modelling method for biodiverse plantings for carbon sequestration. This can assist in demonstrating the co-benefits of carbon planting more accurately.

So one of the issues that we have around uptake of the CFI potentially is the fact that ... the default methodology for the CFI, [the] Reforestation Modelling Tool, [is] based on FulICAM, a type of carbon model. That carbon model was primarily designed around monoculture forestry and does not deal with the complexities of a biodiverse ecosystem planning, environmental planning well and generally underestimates. ... you can see that essentially there's a great discrepancy in the amount of carbon actually sequestered and the amount of carbon you get a credit for, for that model, both in the above ground and below ground. (P5)

This quote emphasises the fact that before introducing a biodiversity standard for carbon plantings we need to be able to predict the precise amount of carbon abatement using welldeveloped carbon models.

\subsection{Market mechanisms to incentivise landholders' participation in biodiverse plantings for carbon sequestration}

We asked interviewees to comment on two scenarios for incentivising landholders' participation in biodiverse plantings for carbon sequestration schemes - bundling (premium carbon) and stacking biodiversity and carbon credits - in addition to the status quo (business as usual). The potential of each option and their market and policy-related constraints are discussed here. 


\subsubsection{Status quo: Payments for carbon or assistance from the Biodiversity Fund}

Currently, landholders are only paid for carbon credits, although a minority are able to receive financial assistance from the Biodiversity Fund (Australian Government, 2013). Only one of the policy experts stated that the status quo will work well to incentivise both carbon abatement and biodiversity conservation. He reflected on the point that incentives like the Biodiversity Fund could facilitate landholders' participation in the CFI. The Biodiversity Fund was introduced as a part of the Australian Government's Land Sector Package of the Clean Energy Future plan to provide incentives for landholders to undertake revegetation activities to restore landscape and conserve biodiversity (Australian Government, 2013). The first round of funding (AUD\$270 million) was offered in 2011-2012 for 312 projects across Australia, followed by the second round for 2013-14, funding 18 successful projects (Australian Government, 2013).

So yes, there certainly is enough incentive for landholders. At this moment in time, through the Biodiversity Fund and through the Native Vegetation so, there's a CFI methodology for native vegetation, and that covers both maintaining and improving existing things as well as planting new native vegetation. (P3)

If the Biodiversity Fund continues operation after 2014, it could assist landholders to cover the additional establishment costs for biodiverse plantings for carbon sequestration. However, P3 believes that innovative methods for incentivising landholders are not essential.

\subsubsection{Premium carbon: bundling carbon and biodiversity credits}

Standards for premium carbon have been part of the international voluntary carbon market for less than a decade (the first Climate, Community and Biodiversity Standards (CCBS) were released in 2005 (CCBA, 2013)); however, these standards are not yet in place in Australia. Several interviewees championed the feasibility of bundled carbon and biodiversity credits from both market and policy perspectives. One research participant mentioned the value of extra incentives for landholders to undertake revegetation activities, covering the establishment costs in particular.

...situations where you've got potential for both carbon and biodiversity and the carbon price alone isn't enough ... you could certainly imagine a conservation agency paying farmers an additional premium... you know we'll pay you, we'll give you an incentive to 
plant trees here. You can keep the carbon credits and sell them so that will give you some money, but we think that's not enough so we'll give you some extra, but we want ... you know, particular mixed species and mixed understorey, whatever type of planting they wanted for biodiversity so yeah, you know it's certainly straightforward to do that. (S2)

As S2 mentioned, providing extra financial support for landholders through payments for biodiversity conservation could benefit the landscape. Some of the interviewees stated that financial incentives could be employed as a capacity building tool in a broader scale (e.g. catchment).

There are many different instruments and they span the total spectrum of increasing knowledge and ability to act through building local or catchment base capability through providing financial incentives through bundling credits. (S6)

Other respondents agreed that a conservation agency could govern the bundled carbon credits and pay landholders more for the landscape restoration and biodiversity benefits of those trees. One noted:

It won't pay for stuff that's been established in the past, but if stuff's been established now and they're getting biodiversity credits, that's fine. You can only sell the carbon once, but if you're getting other stuff from it, then that's fine. So yeah, so that certainly would work as a premium on top of carbon credits. (S1)

Other interviewees were similarly positive about the possibility that other actors (e.g. financial institutions) in the market would support bundled credits to benefit landscape.

...the development of that market is occurring as we speak. You've already got banks and other investors who are looking at what's occurring under the CFI and saying "Oh that's all well and good but we want to ensure that what we do has multiple benefits for the landscape and the people in those regional areas." So we're not prepared just to say go make sure you sequester 5,000 tonnes of carbon. We want you to go sequester 5,000 tonnes of carbon and demonstrate what the additional environmental benefits are. (P5) 
Premium carbon could enable the stakeholders in carbon and biodiversity markets to introduce a set of standards that could prove the additional co-benefits that carbon sequestration activities offer.

\subsubsection{Stacking credits}

When designed carefully, stacking could provide positive ecological benefits (EPRI, 2011). Some of the interviewees asserted that stacking carbon and biodiversity credits could work as a mechanism to allow both credits to be earned from one piece of private land.

Landholders should be able to just register where their permanent plantings are, for example, and receive benefits from [them]. There should be the allowance to use carbon offsets and biodiversity offsets on the same project. (P7)

As P7 expressed, the fact that these trees are permanent guarantees the biodiversity cobenefits for the landscape. Others mentioned that reforestation provides multiple services and landholders could have the opportunity of benefits from multiple markets for ecosystem services.

But when you've got a biodiversity outcome and you've got a carbon outcome I think it's a reasonable expectation that you could ... market that to both of those two values. ... the same individual trees provide the same service across both of those but you are very much providing two services by the provision of that reforestation activity. So I think it's a reasonable expectation that you should be able to engage with multiple markets for the same trees if the ecosystem services they're providing are quite different. (P2)

The feasibility of stacking carbon and biodiversity credits and the way market and legislation deals with the issue was discussed with both policy experts and academics in this study. One noted:

Obviously the legislation finds that a very complex issue to deal with. The CFI looks at the tree and says "Well you're planting the tree for biodiversity, you're getting paid for biodiversity, you can't get paid for the carbon", which is nonsensical from my 
perspective. You're providing multiple benefits so you should potentially be able to engage in multiple markets. (54)

Furthermore, some respondents reflected that policy could be changed easily in favour of both markets.

Quite simply, just allow it. A stroke of a pen - it's a policy construct; it's not like it's market-driven. It's a policy. At the moment... you can't do both on the same project although you're getting the benefits. I mean, why are landfill gas abatement projects allowed to create electricity, generate carbon credits, not register it on the land and also reduce their impact of the carbon tax? They get to dip three times. Carbon gets to dip once. (P7)

P7 stressed that policies should be more flexible in favour of carbon plantings. One of the interviewees argued that the permanence rule should not be considered a hurdle in the stacking process. He also reflected that one streamlined policy design across Australia would be useful.

They can get rid of the permanence rule quite easily by getting a consistence across the states, the multi-jurisdictional boundaries, by saying that once you've done a carbon planting and it gets 10 years of age, it goes into the biodiversity offset market. Or what it does is ... you're covered by the native EPBC Act [The Environment Protection and Biodiversity Conservation Act 1999] that after 10 years it's there permanently and if you cut it down you have to replace it. And if you replace it you don't get carbon credits 'cause you're just balancing out what you cut down. (P2)

Interviewees opposed to stacking carbon and biodiversity credits stated that additionality was the main barrier to introducing the stacked credits and stacking could jeopardise the integrity of the carbon market.

Well a market operates on the integrity of the product. Additionality - with permanence - is one of the defining characteristics of a carbon credit. If you remove that concept of additionality then you can't be sure that the work you're doing in that project is in fact 
reducing emissions and if it's not reducing emissions it devalues the product across all carbon credits. (P8)

As reflected above, additionality as one of the main requirements of an offset project to demonstrate the real gain in emissions reduction could act as a barrier in the credit stacking process. However, from the perspective of landholders, additionality could act as a barrier in the carbon market as it influences their willingness to revegetate permanently on their properties. Here, we interrogated other stakeholders' perspective about additionality as a barrier.

Figure 2 presents a broad summary of the opinions of interviewees regarding the appeal of the three policy scenarios. It represents the incentives each of the options provides for landholders and also the possible market and policy constraints in implementing each of these options. We assigned different actors to groups based on the risks and opportunities they mentioned regarding each option. Grouping also reflects that some interviewees were opposed to a specific scenario or in favour of the other one.

Market and Policy

Constraints

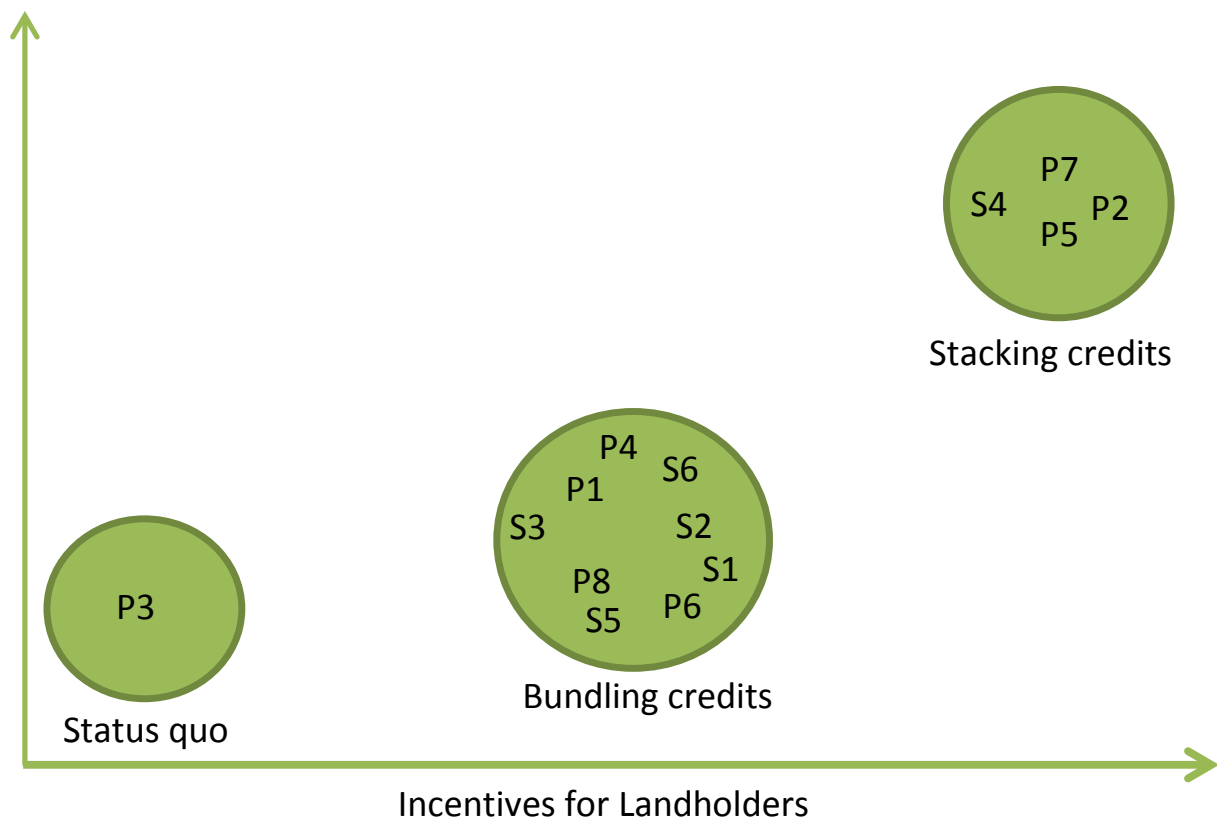

Figure 2: The broad position of interviewees on various options of integrating carbon and biodiversity markets. ' $P$ ' identifies policy-related interviewees and ' $S$ ' scientific experts.

Note: Status quo includes both existing regulation and using the Biodiversity Fund to help establish biodiverse plantings for carbon sequestration. Bundling is defined as 'premium carbon' (a higher price for co-benefits), and stacking refers to selling both biodiversity and carbon on the one piece of land. 


\section{Discussion}

The power of this bundling of nature into tradeable bits of capital should not be underestimated, but nor should it be exaggerated. (Smith 2007 p.24)

The idea of bundling or stacking ecosystem services has gained considerable international attention, recognising that both buyers and sellers in the market could gain from its benefits (Bryan, 2013; Deal et al., 2012; Turner et al., 2014). In the case of carbon sequestration and biodiversity conservation, carefully designed bundling or stacking scenarios could benefit both objectives (Standish and Hulvey 2014; Venter et al. 2009). In this paper, we presented the expert opinions of policy makers and academics in Australia about the possibility of integrating the carbon and biodiversity ecosystem services markets. Previous research (EPRI 2011) presents evidence of a general preference against stacking. What the current research adds beyond this is a substantial unpacking of the reasons behind that preference. We present a discussion of the nature and extent of challenges and opportunities for stacking and bundling credits, based on our elicitation of practioners' experiences in the field. We also build upon the theoretical suggestions of Robertson et al (2014) and Cooley and Lander (2011) to develop practical, grounded recommendations.

As a preliminary step we discussed the need for a driving force in the market from the buyers' side to create the demand for such integration. CSR is the driver behind businesses participation and motivates their willingness to pay extra money for bundled or stacked credits. Businesses allocate budget not only to have a green image but to save money through environmental efficiency measures (Clapp and Rowlands 2015; Schmidheiny 1992). However, political and carbon market uncertainties act as barriers for developing integrated credits. This echoes findings of previous research about the concerns of both buyers and sellers regarding uncertainties in the market and policy setting (Kragt et al. 2014; Maraseni and Dargusch 2008; Kapambwe and Keenan 2009).

Before designing and introducing new bundled or stacked credits we need to focus on prioritising conservation objectives at a landscape scale and developing accurate carbon modelling techniques for biodiverse plantations. These two enhancements would provide confidence to buyers in the carbon and biodiversity markets so that genuine improvements in 
both carbon and biodiversity outcomes could be delivered. Landscape-scale restoration has been the subject of many studies from various perspectives and levels (Goldman et al., 2007; Menz et al., 2013; Shea, 2003; Sorice et al., 2013), and as our paper suggests it is one of the essential elements in delivering tangible biodiversity outcomes from carbon plantings. This is not only to find fragmented landscapes where immediate action is required (e.g. landholder's engagement with higher incentives) but to locate synergistic ecosystem services (Onaindia et al., 2013) to achieve both conservation goals and higher return on investment. Some of the institutions involved in multiple ecosystem services credits also use prioritization to allocate their funding for conservation more efficiently (Willamette Partnership, 2013). Zonation (Watts et al., 2009) is an example of spatial prioritization software that could easily incorporate 'potential for carbon sequestration'. Identifying priority sites for restoration could potentially include carbon sequestration potential as additional criteria.

We argue that before introducing a bundling or stacking scenario for carbon and biodiversity credits we need to answer the question 'what does this bundling or stacking want to achieve?', and then incentivise landholders in relevant parts of the landscape. Some of the interviewees also reiterated previous calls for improved models of carbon sequestration of biodiverse plantings (Paul et al., 2013).

We classified interviewees' responses into three scenarios regarding future biodiverse plantings for carbon sequestration scenarios: status quo (with assistance from Biodiversity Fund), bundling credits and stacking credits. Status quo refers to undertaking biodiverse plantings for carbon sequestration through the aid of the Biodiversity Fund as an additional incentive for landholders to participate in a scheme like CFI. This scenario does not require any changes in market or policy obligations but provides minimum assistance and incentives for landholders to participate in the carbon farming schemes. Only one policy expert expressed confidence in this approach (see Figure 2).

In contrast, the scenario of bundling credits (selling premium carbon at a higher price to the carbon market) was supported by the majority of interviewees (Figure 2). This is because opportunities for policy change in the bundled credits scenario seem more feasible. Such an approach could streamline landholders' participation in a carbon planting scheme to achieve both biodiversity and carbon abatement goals (Standish and Hulvey 2014). Bundling could also reduce the administrative costs of the schemes. However, the lack of standards in Australia to 
demonstrate that the desired biodiversity gains have been achieved is one of the obstacles in introducing and designing bundled credits. Developing Australian standards or implementing existing international standards will assist both buyers and sellers in the carbon market. Such standards need to clearly demonstrate the co-benefits of carbon plantings. Similar standards exist in the international voluntary market (e.g., CCBS (CCBA, 2013)). Adopting related standards has several merits. One of the advantages of such standards is the fact that the process of biodiversity monitoring is incorporated in the carbon monitoring, saving time and resources. The Emissions Biodiversity Exchange Project for the 21st Century (EBEX 21), a program of Landcare Research New Zealand, demonstrated this approach to monitoring (Landcare Research, 2015; Maraseni and Dargusch, 2008). Transparency in the policy and market are a further prerequisite for success. Procedures should be in place to streamline offering higher prices for the co-benefits of biodiverse plantings for carbon sequestration without additional complexities in a program.

Stacking credits could face more political and market-related constraints. This is because of the additionality requirements of carbon and biodiversity offsets. Trading stacked credits on the international market is not currently permissible. The other challenge in stacking credits is the missed opportunity for restoring another piece of land that could otherwise have been managed for biodiversity purposes. Yet it is the opportunity to reduce management costs that is a key advantage of stacking carbon and biodiversity markets. In addition, the revegetated sites for carbon sequestration need regular monitoring and the permanence rule of carbon planting schemes requires those trees to stay on landholders' properties for 100 years. This could guarantee the biodiversity and restoration benefits of those trees in the landscape. (Landcare Research, 2015; Maraseni and Dargusch, 2008). Furthermore, in the 'stacked credits' scenario, Interviewees expressed their concerns about the integrity of the carbon market, specifically regarding the additionality requirement. However, the recent release of the Draft NSW Biodiversity Offsets Policy for Major Projects (yet to be finalised) presents an opportunity for policy change in favour of both carbon and biodiversity (State of NSW and Office of Environment and Heritage, 2014).

Similar challenges and opportunities exist in bundling and stacking credits in countries other than Australia. For example, carbon and water nutrient credit stacking effectively incentivised landholders in the USA. However, Lankoski et al. (2015) highlight the risk that this approach may 
be creating an oversupply in the market, which could result in reduced prices and the future non-profitability of such credits for landholders. This reality has been realised in a scheme in North Carolina, involving the stacking of wetland and water quality credits. In this case, oversupply of credits and concerns regarding additionality led to the discontinuation of this program.

Howard et al. (2015) challenge the idea of 'fair carbon' in scenarios where social and environmental co-benefits (in standards like Plan Vivo and CCBs) are bundled with the carbon credits. Social justice challenges arise when land tenure and carbon rights are linked together, or the benefits are not distributed fairly in the community. They also argue that environmental challenges occurred when achievable co-benefits at the outset of a bundled ecosystem services project were not defined (Howard et al 2015; Shames et al 2010). These international examples stress the careful design of any bundled or stacked credits of ecosystem services to achieve desired socio-ecological outcomes.

Finally, existing challenges in the carbon and biodiversity markets could influence the success of introducing new methods to incentivise landholders. We unpacked some of these challenges (e.g. uncertainty in policy and market). These uncertainties could reduce the innovation in the market for ecosystem services (e.g. bundling). Additionality as one of the legal requirements of carbon and biodiversity offsets reduces the popularity of stacking credits. Opponents of stacking credits argue that stacking credits on one piece of property is a missed opportunity for conservation of another part of landscape. However, bundling opponents express their concerns about the lack of standards to show robust biodiversity gains.

\section{Conclusions}

The findings presented in this research make a novel contribution to current debates in the literature and in policy design regarding bundling or stacking payments for ecosystem services. To achieve both public benefits and improvement in management of natural assets, the cobenefits of ecosystem services require greater attention. Recognition of these co-benefits could assist in achieving ecological restoration objectives, particularly in highly fragmented landscapes. 
We argue that careful policy design is crucial when considering stacking and bundling scenarios given the complex trade-offs between different ecosystem services (e.g. compromising biodiversity by planting mono-cultures for more carbon credits). Policymakers must consider what a bundling or stacking credit scenario aims to achieve in terms of both landscape restoration and carbon sequestration. Carbon market rules (in particular the additionality requirement) make stacking credits a more complicated option. In our study, designing bundled credits (premium pricing for biodiversity benefits of carbon plantings) that could provide landholders with financial assistance for transaction costs was deemed a more viable policy alternative than stacking or the status quo. However, the success of any of the incentivizing scenarios depends on higher certainty in both carbon markets and political settings. This is crucial to attract both buyers and sellers in the market to achieve the desired biodiversity conservation and carbon abatement outcomes. In addition, there is a clear need for standards that measure carbon planting co-benefits (e.g. biodiversity), and better techniques for modelling sequestered carbon from biodiverse plantings for carbon sequestration to improve the design of bundled/stacked credits. Although these incentives lower the transaction costs for landholders and could increase their participation rate, the initial cost for designing the standards, improving the modeling techniques and designing a scheme that offers such flexibilities may be considered a barrier for policy makers. Finally, biodiversity conservation and carbon sequestration interact; this highlights the need for careful design of the best policy option to achieve both goals by fostering synergies between ecosystem services.

\section{Acknowledgements}

This research was conducted with the support of funding from the Australian Government's National Environmental Science Program and the Australian Research Council Centre of Excellence for Environmental Decisions. Sarah Bekessy is supported by an ARC Future Fellowship.

\section{References}

Australian Government, 2013. Biodiversity Fund [WWW Document]. URL http://www.environment.gov.au/cleanenergyfuture/biodiversity-fund/index.html (accessed 9.1.14). 
Australian Government, 2011. Carbon Farming Initiative [WWW Document]. URL http://www.daff.gov.au/climatechange/cfi

Australian Governmet, 2013. About the CFI, Total number of Australian carbon credit units (ACCUs) issued in Q2 of 2013 - 14. Canberra.

Baral, H., Keenan, R.J., Stork, N.E., Kasel, S., 2014. Measuring and managing ecosystem goods and services in changing landscapes: a south-east Australian perspective. J. Environ. Plan. Manag. 57, 961-983. doi:10.1080/09640568.2013.824872

Bekessy, S.A., Wintle, B.A., 2008. Using Carbon Investment to Grow the Biodiversity Bank. Conserv. Biol. 22, 510-513. doi:10.1111/j.1523-1739.2008.00943.x

Boyatzis, R.E., 1998. Transforming Qualitative Information: Thematic Analysis and Code Development. Sage Publications, Thousand Oaks, CA.

Bradshaw, C.J. a., Bowman, D.M.J.S., Bond, N.R., Murphy, B.P., Moore, A.D., Fordham, D. a., Thackway, R., Lawes, M.J., McCallum, H., Gregory, S.D., Dalal, R.C., Boer, M.M., Lynch, a. J.J., Bradstock, R. a., Brook, B.W., Henry, B.K., Hunt, L.P., Fisher, D.O., Hunter, D., Johnson, C.N., Keith, D. a., Lefroy, E.C., Penman, T.D., Meyer, W.S., Thomson, J.R., Thornton, C.M., VanDerWal, J., Williams, R.J., Keniger, L., Specht, A., 2013. Brave new green world - Consequences of a carbon economy for the conservation of Australian biodiversity. Biol. Conserv. 161, 71-90.

Bryan, B.A., 2013. Incentives, land use, and ecosystem services: Synthesizing complex linkages. Environ. Sci. Policy 27, 124-134. doi:10.1016/j.envsci.2012.12.010

Bryman, A., 2004. Social Research Methods, Second Edi. ed. Oxford University Press, Oxford.

Burgin, S., 2008. BioBanking: an environmental scientist's view of the role of biodiversity banking offsets in conservation. Biodivers. Conserv. 17, 807-816. doi:10.1007/s10531008-9319-2

Cacho, O.J., Lipper, L., Moss, J., 2013. Transaction costs of carbon offset projects: A comparative study. Ecol. Econ. doi:10.1016/j.ecolecon.2012.12.008

Carswell, F., Burrows, L., 2006. Could biodiversity add value to New Zealand's Kyoto forest credits? NZ J. For.

CCBA, 2013. Climate, Community \& Biodiversity Standards Third Edition. Arlington, VA, USA.

Clapp, J., Rowlands, I.H., 2015. Corporate Social Responsibility, in: Morin, J.-F., Orsini, A. (Eds.), Essential Concepts of Global Environmental Governance. Rotledge, Oxon, pp. 41-44.

Commonwealth of Australia, 2014. Emissions Reduction Fund White Paper. Canberra. 
Commonwealth of Australia, 2013. Emissions Reduction Fund Green Paper. Canberra, Australia.

Cooley, D., Olander, L., 2011. Stacking Ecosystem Services Payments Risks and Solutions Risks and Solutions. Nicholas Inst. Work. Pap. Duke Univ.

Crossman, N.D., Bryan, B.A., Summers, D.M., 2011. Carbon Payments and Low-Cost Conservation. Conserv. Biol. 25, 835-845. doi:10.1111/j.1523-1739.2011.01649.x

Deal, R.L., Cochran, B., LaRocco, G., 2012. Bundling of ecosystem services to increase forestland value and enhance sustainable forest management. For. Policy Econ. 17, 6976. doi:10.1016/j.forpol.2011.12.007

Department of Sustainability and Environment, 2011. What is BushBroker? [WWW Document]. URL http://www.dse.vic.gov.au/conservation-andenvironment/biodiversity/rural-landscapes/bushbroker

Di Giuli, A., Kostovetsky, L., 2014. Are red or blue companies more likely to go green? Politics and corporate social responsibility. J. financ. econ. 111, 158-180. doi:10.1016/j.jfineco.2013.10.002

Drever, E., 1995. Using sem-structured interviews in small-scale research. The Scottish Council for Research in Education, Edinburgh.

EPRI, 2011. U . S . National Opinion Survey on Stacking Environmental Credits: Defi nition, Status, and Predictions of Wetland, Species, Carbon, and Water Quality Credit Stacking. Palo Alto.

Fargione, J., Hill, J., Tilman, D., Polasky, S., Hawthorne, P., 2008. References and Notes 1. Science (80-. ). 319, 1235-1239.

Freedman, B., Stinson, G., Lacoul, P., 2009. Carbon credits and the conservation of natural areas. Environ. Rev. 17, 1-19. doi:10.1139/A08-007

Galik, C.S., Cooley, D.M., Baker, J.S., 2012. Analysis of the production and transaction costs of forest carbon offset projects in the USA. J. Environ. Manage. 112, 128-36. doi:10.1016/j.jenvman.2012.06.045

Glaser, B.G., Strauss, A.L., 1967. The Discovery of Grounded Theory: Strategies for Qualitative Research. Aldine Publishing Company, Chicago.

Goldman, R.L., Thompson, B.H., Daily, G.C., 2007. Institutional incentives for managing the landscape: Inducing cooperation for the production of ecosystem services. Ecol. Econ. 64, 333-343. doi:10.1016/j.ecolecon.2007.01.012

Gordon, A., Langford, W.T., Todd, J.A., White, M.D., Mullerworth, D.W., Bekessy, S.A., 2011a. Assessing the impacts of biodiversity offset policies. Environ. Model. Softw. 1-8. 
Gordon, A., Langford, W.T., White, M.D., Todd, J.A., Bastin, L., 2011b. Modelling trade offs between public and private conservation policies. Biol. Conserv. 144, 558-566.

Horan, R.D., Shogren, J.F., Gramig, B.M., 2008. Wildlife conservation payments to address habitat fragmentation and disease risks. Environ. Dev. Econ. 13, 415-439. doi:10.1017/S1355770X08004269

Kanowski, J., Catterall, C.P., 2010. Carbon stocks in above-ground biomass of monoculture plantations, mixed species plantations and environmental restoration plantings in north-east Australia. Ecol. Manag. Restor. 11, 119-126. doi:10.1111/j.14428903.2010.00529.x

Kapambwe, M., Keenan, R., 2009. Biodiversity Outcomes from Carbon Biosequestration. Department of Sustainability \& Environment, Melbourne.

Kenny, A., 2010. Theory and Practice Collide in Efforts to Stack Multiple Ecosystem Values on One Piece of Land [WWW Document]. Ecosyst. Marketpl.

Kinzig, A.P., Perrings, C., Chapin, F.S., Polasky, S., Smith, V.K., Tilman, D., Turner, B.L., 2011. Paying for Ecosystem Services - Promise and Peril. Science (80-. ). 334, 603-604.

Kirchner, M., Schmidt, J., Kindermann, G., Kulmer, V., Mitter, H., Prettenthaler, F., Rüdisser, J., Schauppenlehner, T., Schönhart, M., Strauss, F., Tappeiner, U., Tasser, E., Schmid, E., 2015. Ecosystem services and economic development in Austrian agricultural landscapes - The impact of policy and climate change scenarios on trade-offs and synergies. Ecol. Econ. 109, 161-174. doi:10.1016/j.ecolecon.2014.11.005

Kolinjivadi, V., Grant, A., Adamowski, J., Kosoy, N., 2015. Juggling multiple dimensions in a complex socio-ecosystem: The issue of targeting in payments for ecosystem services. Geoforum 58, 1-13. doi:10.1016/j.geoforum.2014.10.004

Kragt, M.E., Blackmore, L., Capon, T., Robinson, C.J., Torabi, N., Wilson, K.A., 2014. What are the barriers to adopting carbon farming practices? Work. Pap. 1407, Sch. Agric. Resour. Econ. Univ. West. Aust.

Landcare Research, 2015. EBEX $21^{\circledR}$ - Kyoto-compliant carbon credits [WWW Document]. URL http://www.ebex21.co.nz/index.asp (accessed 1.10.15).

Lin, B.B., Macfadyen, S., Renwick, A.R., Cunningham, S.A., Schellhorn, N.A., 2013. Maximizing the Environmental Benefits of Carbon Farming through Ecosystem Service Delivery. Bioscience 63, 793-803. doi:10.1525/bio.2013.63.10.6

Madsen, B., Carroll, N., Kandy, D., Bennett, G., Marketplace, E., 2011. 2011 Update : State of Biodiversity Markets, Offset and Compensation Programs Worldwide. Ecosystem Marketplace. 
Maraseni, T.N., Dargusch, P., 2008. Expanding woodland regeneration on marginal southern Queensland pastures using market-based instruments: a landowners' perspective. Aust. J. Environ. Manag. 15, 112-114.

Meijaard, E., Wunder, S., Guariguata, M.R., Sheil, D., 2014. What scope for certifying forest ecosystem services? Ecosyst. Serv. 7, 160-166. doi:10.1016/j.ecoser.2013.12.008

Menz, M.H.M., Dixon, K.W., Hobbs, R.J., 2013. Ecology. Hurdles and opportunities for landscape-scale restoration. Science (80-. ). 339, 526-7. doi:10.1126/science.1228334

Michaelowa, A., 2014. Linking the CDM with domestic carbon markets. Clim. Policy 14, 353371. doi:10.1080/14693062.2014.867177

Office of Environment and Heritage, 2011. BioBanking [WWW Document]. URL http://www.environment.nsw.gov.au/biobanking/

Onaindia, M., Fernández de Manuel, B., Madariaga, I., Rodríguez-Loinaz, G., 2013. Cobenefits and trade-offs between biodiversity, carbon storage and water flow regulation. For. Ecol. Manage. 289, 1-9. doi:10.1016/j.foreco.2012.10.010

Paul, K., Roxburgh, S., Raison, J., Larmour, J., England, J., Murphy, S., Norris, J., Ritson, P., Brooksbank, K., 2013. Improved estimation of biomass accumulation by environmental plantings and mallee plantings using FullCAM. Report for The Department of the Environment. Canberra, Australia.

QSR International, 2012. NVIVO 10 for Windows [WWW Document]. URL http://www.qsrinternational.com/products_nvivo.aspx?utm_source=NVivo+10+for $+\mathrm{M}$ ac (accessed 5.27.14).

Robertson, M., 2012. Measurement and alienation: making a world of ecosystem services. Trans. Inst. Br. Geogr. 37, 386-401. doi:10.1111/j.1475-5661.2011.00476.x

Robertson, M., BenDor, T.K., Lave, R., Riggsbee, A., Ruhl, J.B., Doyle, M., 2014. Stacking ecosystem services. Front. Ecol. Environ. 12, 186-193. doi:10.1890/110292

SCBD, 2010. Global Biodiversity Outlook 3. Montréal.

Schmidheiny, S., 1992. Changing Course: A Global Business Perspective On Development And The Environment. MIT Press, Cambridge, MA.

Shea, S., 2003. The Potential for Large Scale Carbon Sequestration and Landscape and Biodiversity Rehabilitation in Australia. Oil Mallee Co. Aust. Ltd CO2 Aust. Ltd.

Smith, N., 2007. Nature as accumulation strategy. Social. Regist. 19-41.

Sorice, M.G., Oh, C.-O., Gartner, T., Snieckus, M., Johnson, R., Donlan, C.J., 2013. Increasing participation in incentive programs for biodiversity conservation. Ecol. Appl. 23, 114655. 
Standish, R.J., Hulvey, K.B., 2014. Co-benefits of planting species mixes in carbon projects. Ecol. Manag. Restor. 15, 26-29. doi:10.1111/emr.12084

State of NSW and Office of Environment and Heritage, 2014. Draft NSW Biodiversity Offsets Policy for Major Projects. Sydney.

Turner, K.G., Odgaard, M.V., Bøcher, P.K., Dalgaard, T., Svenning, J.-C., 2014. Bundling ecosystem services in Denmark: Trade-offs and synergies in a cultural landscape. Landsc. Urban Plan. 125, 89-104. doi:10.1016/j.landurbplan.2014.02.007

Tvinnereim, E., 2014. The bears are right: Why cap-and-trade yields greater emission reductions than expected, and what that means for climate policy. Clim. Change. doi:10.1007/s10584-014-1282-1

Van der Biest, K., D’Hondt, R., Jacobs, S., Landuyt, D., Staes, J., Goethals, P., Meire, P., 2014. EBI: An index for delivery of ecosystem service bundles. Ecol. Indic. 37, 252-265. doi:10.1016/j.ecolind.2013.04.006

Venter, O., Laurance, W.F., Iwamura, T., Wilson, K.A., Fuller, R.A., Possingham, H.P., 2009a. Harnessing Carbon Payments to Protect Biodiversity. Science (80-. ). 326, 1368. doi:10.1126/science.1180289

Venter, O., Meijaard, E., Possingham, H., Dennis, R., Sheil, D., Wich, S., Hovani, L., Wilson, K., 2009b. Carbon payments as a safeguard for threatened tropical mammals. Conserv. Lett. 2, 123-129. doi:10.1111/j.1755-263X.2009.00059.x

Verchot, L. V., Van Noordwijk, M., Kandji, S., Tomich, T., Ong, C., Albrecht, A., Mackensen, J., Bantilan, C., Anupama, K. V., Palm, C., 2007. Climate change: linking adaptation and mitigation through agroforestry. Mitig. Adapt. Strateg. Glob. Chang. 12, 901-918. doi:10.1007/s11027-007-9105-6

Waterworth, R.M., Richards, G.P., 2008. Implementing Australian forest management practices into a full carbon accounting model. For. Ecol. Manage. 255, 2434-2443. doi:10.1016/j.foreco.2008.01.004

Watson, J., Kern, F., Markusson, N., 2014. Resolving or managing uncertainties for carbon capture and storage: Lessons from historical analogues. Technol. Forecast. Soc. Change 81, 192-204. doi:10.1016/j.techfore.2013.04.016

Watts, M.E., Ball, I.R., Stewart, R.S., Klein, C.J., Wilson, K., Steinback, C., Lourival, R., Kircher, L., Possingham, H.P., 2009. Marxan with Zones: Software for optimal conservation based land- and sea-use zoning. Environ. Model. Softw. 24, 1513-1521. doi:10.1016/j.envsoft.2009.06.005

Willamette Partnership, 2013. Willamette Partnership Ecosystem Credit Accounting System: General Crediting Protocol Version 2.0. Portland. 
Woodward, R.T., 2011. Double-dipping in environmental markets. J. Environ. Econ. Manage. 61, 153-169. doi:10.1016/j.jeem.2010.07.004 